\title{
INTERACTION EFFECT OF COUNTRY OF MANUFACTURE AND BRAND AWARENESS ON MALAYSIAN YOUNG ADULTS PURCHASE INTENTION OF LOW INVOLVEMENT PRODUCT
}

\author{
WPŁYW INTERAKCJI POMIĘDZY KRAJEM PRODUKCJI A ŚWIADOMOŚCIĄ MARKI NA INTENCJĘ \\ ZAKUPU PRODUKTU O NISKIM STOPNIU ZAANGAŻOWANIA PRZEZ MŁODYCH DOROSŁYCH W MALEZJI
}

\author{
Chui Seong Lim \\ Faculty of Business, Economics and Accounting and Economic \\ HELP University, 50490 Kuala Lumpur, Malaysia \\ chuiseong.lim@help.edu.my •ORCID 0000-0001-7243-8405
}

\section{Kay Tze Hong}

Faculty of Business and Law, School of Management and Marketing

Taylor's University, 47500 Subang Jaya, Selangor

kaytze.hong@taylors.edu.my • ORCID 0000-0002-9336-4131

\section{Siew Chin Wong}

Faculty of Business, Economics and Accounting and Economic

HELP University, 50490 Kuala Lumpur, Malay

sc.wong@help.edu.my• ORCID 0000-0003-1779-4778

\section{Louisa Hew Wei Yee}

Faculty of Business, Economics and Accounting and Economic

HELP University, 50490 Kuala Lumpur, Malay

louisa439@hotmail.com.

DOl: 10.2478/minib-2021-0004

\section{ABSTRACT}

This study aims to examine the interaction effect of country of manufacture and brand awareness, packaging and price impact on the purchase intention of toothpaste among young adults in Malaysia. As previous studies show, the country of origin should not be taken as a single clue, as it exaggerates the country of origin effect. This study evaluates the effect of the country of origin effect on the low-involvement good (toothpaste). The Cue Utilization Theory was used to explain how the consumer uses product cues to rate a product before making a purchase decision. Study data are analysed using SmartPLS. The results of this study showed that all variables influence consumer purchase intention for toothpaste. IPMA analysis showed that the interaction effect of the country of manufacture and brand awareness are important factors.

Key words: Country of Manufacture, Brand Awareness, Interaction, Low Involvement Product, Importance and Performance Matrix (IPMA) 


\section{ABSTRAKT}

Celem niniejszego opracowania jest zbadanie wpływu interakcji pomiędzy krajem produkcji a świadomością marki, opakowaniem i ceną na intencję zakupu pasty do zębów wśród młodych dorosłych w Malezji. Jak pokazują wcześniejsze badania, kraj pochodzenia nie powinien być traktowany jako pojedyncza wskazówka, ponieważ wyolbrzymia on efekt kraju pochodzenia. Niniejsze badanie ocenia wpływ efektu kraju pochodzenia na dobro o niskim stopniu zaangażowania (pastę do zębów). Teoria Wykorzystania Wskazówek została wykorzystana do wyjaśnienia, w jaki sposób konsument wykorzystuje wskazówki dotyczące produktu do oceny produktu przed podjęciem decyzji o zakupie. Dane z badania analizowane są za pomocą programu SmartPLS. Wyniki badania wykazały, że wszystkie zmienne wpływają na intencję zakupu pasty do zębów przez konsumenta. Analiza IPMA wykazała, że efekt interakcji kraju produkcji i świadomości marki są istotnymi czynnikami.

Słowa kluczowe: Kraj produkcji, świadomość marki, interakcja, produkt o niskim zaangażowaniu, IPMA

JEL: M31

\section{Introduction}

Previous studies have shown that the country of origin (COO) of a product influences consumers' purchasing decisions (Degoma \& Shetemam, 2014; de Run, Chan, Khalique, 2012). This is especially true if the consumer does not have much information about a given product; therefore, the consumer would use the $\mathrm{COO}$ of a product to assess its quality (de Run et al., 2012). The economic development of a country also affects consumers' purchasing decisions for foreign goods (Ghazali, Othman, Yahya, Ibrahim, 2008). Consumers are often of the opinion that goods produced in an industrialised country are considered to be better 
than products from a developing country (Wang \& Lamb, 1983) and have more confidence in products from developed countries because they are considered high-quality or high-performance (Kaynak, Kucukemiroglu \& Hyder, 2000). Malaysian consumers consider goods from developed countries to be of high quality compared to local goods (Lew and Sulaiman 2013). Multinationals often turn to developing countries for manufacturing or assembling their products because of their low production costs (Prendergast, Tsang \& Chan 2010). Therefore, there are many consumer goods such as toothpaste from major brands in developed countries, are made in developing countries such as Thailand, Malaysia, China and Vietnam. Thus, the study of country of origin effect is becoming increasingly useful as it provides information that helps to better market or develop products, especially fast-moving consumer goods such as toothpaste, which has a consumption of 3.89 billion units in the Asia Pacific for the year 2017 alone and is expected to reach $\$ 13.06$ billion by 2023 in the Asia Pacific alone (Mordor Intelligence 2019). Studies such as Kala and Chaubey (2016), Olawepo \& Ibojo (2015) and many more have shown that product clues have impact on consumer choices; however, there is few research that focuses on the interaction of clues such as country of origin/manufacturing and brand awareness that impact on the purchase intention of low involvement products whereby many brands manufactured their products in developing countries.

\section{Review of Literature}

\section{Cue Utilisation Theory}

Cue utilisation theory explains that products have several clues that indicate product quality, and these clues are used by consumers to evaluate the quality of the products (Rao \& Monroe, 1988). Product quality assumptions are often made based on the advice available to consumers (Acebron \& Dopico, 2000). Product cues are used as heuristics in the evaluation of product quality if (1) the consumer wishes to reduce the purchasing risk, (2) the consumer does not have sufficient knowledge to evaluate the product quality, (3) the purchase 
with low involvement, (4) actual quality is too complicated to be assessed or (5) the consumer does not have the time to make a comprehensive evaluation of the quality of the products (Dawar \& Parker, 1994). Therefore, with the use of product cues, the consumer's purchasing decision process for low-involvement goods can be simplified.

Product cues are divided into extrinsic and intrinsic cues. Intrinsic cues are physically related to the product itself and can only be changed if the product's properties are changed (Pezoldt, Michaelis, Roschk \& Geigenmueller, 2014). Examples of intrinsic cues are fragrance or ingredients. While extrinsic cues are product attributes that are not physically part of the product, such cues include country of origin, packaging, price, brand or warranty (Pezoldt et al., 2014). Extrinsic cues are usually more visible than intrinsic cues. Consumers are generally more likely to rely on extrinsic factors when assessing product quality, as they may not have access to the products intrinsic cues or have inadequate information about the products (Acebron \& Dopico, 2000). Therefore, the extrinsic indication can be used as a quality signal of a product and in turn affect the overall consumer rating of the product (Bayraktar, Uslay $\&$ Ndubisi, 2015). Studies have used cue utilisation theory to investigate producer's credibility to reduce customers' risk in adopting a product (Helm $\&$ Mark 2007) and to examine the role of product knowledge and product choice cues (Bruwer, Chrysochou \& Lesschaeve, 2017). Conversely, this study employs the cue utilisation theory by focusing on country of manufacture and brand awareness as a signal to stimulate consumers' intention to purchase a low-involvement product such as toothpaste.

\section{Purchase Intention}

Behavioural intentions, such as purchase intention is often used as a predictor and probability of committing actual behaviour (Lim \& Omar 2019). It is referred to as "the subjective probability that a person will perform certain behaviours" (Fishbein and Ajzen, 1975, pp.288). In other words, if a person has a greater willingness to purchase a particular product, the likelihood that they will purchase the product is higher, but not necessarily purchasing it. Many studies used the purchase intention to 
predict the likelihood to use including patients' intention to use the mobile health app (Tung, Lim \& Wong 2019), young adults' intention to use mobile health app (Gow, Wong \& Lim, 2019), single e-payment system (Lai \& Lim 2019) and to purchase store brands (Tih \& Heng 2017). It has also been found that the perception of consumers, country of origin, and the perception of country of origin influence customers' purchase intention (Wang, Li, Barnes \& Ahn, 2012).

\section{Country of Origin \& Country of Manufacture (COM)}

The country of origin ( $\mathrm{COO}$ ) can be defined as the country where the company headquarter is located (Rezvani, Javadian, Sabbir, Fouladivanda, Habibi \& Eghtebasi, 2012), or as the country in which the manufacturer's product or brand is identified with, which is referred to as the "home country" (Saeed, 1994). It is an outward indication that influences consumer attitudes and perceptions, product evaluation and purchase intention (Yang, Ramsaran \& Wibowo, 2016; Chinen, Jun \& Hampton 2000).

The COO effect can be observed in two ways: (1) halo effect and (2) summary construct. Halo effect happens when the consumer is unfamiliar with certain foreign goods, the country image is used to assess product quality (Han, 1989). The COO indicator is used as a reference for product quality and reliability, which simplifies the information processing process (Ozretic, Skare \& Krupka, 2007) whereas the summary construct effect occurs when the consumer is familiar with the goods of a country. The reason for this is that the consumer assumes that products have similar characteristics when they come from the same country and therefore can aggregate information about products from a particular country (Han, 1989). This then affects the consumer's desire to purchase products from that particular country (Dharmadasa \& Chanaka, 2017). According to the findings of Kala and Chaubey (2016), COO information has a major effect on young Indian consumers' value product quality and technological progress through $\mathrm{COO}$ information and purchasing decisions.

In this study, the country of origin is defined as the country where goods are manufactured, also known as the manufacturing country (COM). The 
image of the COM is often used by consumers to judge whether a product is good because of their perception of that country (Yasin, Noor \& Mohamad, 2007). For example, when Honda and Mazda relocate their factories from Japan to Mexico and the Philippines, this reduces their attractiveness (Lee, Lee. \& Lee. 2013). While Haier, a Chinese electronics and equipment manufacturer, has improved its image through manufacturing in the United States (Lee et al., 2013). The image of COM has a significant effect on consumer purchase intention (Degoma \& Shetemam 2014) and this is especially true when the COM has an unfavourable image as a consumer is likely to have an unfavourable perception of products from that country (Lin \& Chen, 2006).

Majority of consumers prefer products from developed countries such as America or Europe as they are considered of high quality while products from less developed or developing countries are perceived of lower quality (Chinen et al., 2000). Some brands labelled products manufactured in developing countries with lower prices. Therefore, before purchasing a particular product, the consumer can assess the country of manufacture of the product with known brands from the developed countries.

\section{Brand Awareness}

Brand awareness is defined as the consumer's ability to recall or recognize that a brand is part of a particular product category (Aaker, 1991) and product characteristics (Keller 1993). A product has a high brand awareness when the brand name is the first thing the consumer thinks about when making a purchase decision (Hsin, Ren \& Ya, 2009).

Brand awareness is important for several reasons. Firstly, it is important that, given a high level of consumer awareness of a particular brand, that brand is likely to be included in the consumer's considerations that are made in the purchase decision. Secondly, consumers' purchasing decision of brands among consideration set can be influenced by brand awareness, even though there is no brand associated with it (Keller, 1993). For example, consumers often tend to purchase only known or popular brands. Therefore, brand awareness alone can influence consumers' purchasing decisions, and this applies in particular to low-involvement 
purchasing decisions (Hoyer \& Brown, 1990). The more conscious consumers are of a particular brand, the higher the likelihood that the brand will be bought by consumers (Motale \& Dhurup 2016). This is consistent with the research done by Hsin, et al (2009), that is, the higher the brand awareness, the higher the purchase intention.

\section{Interaction Effect of the country of manufacturing and brand awareness}

Studies have shown that COM, despite brand awareness, has an effect on brand personality. In the study of automobile manufacturers, COM has a stronger personality in industrialized countries (Fetscherin \& Toncar 2010). Other studies have shown that durable products such as cars and washing machines from developing countries affect the attractiveness and brand image (Lee et al., 2013). However, limited studies have investigated the interaction effect of $\mathrm{COO}$ and BA especially on known and famous brand with manufactured products in the developing countries. In this study, we investigated the effect of combined brand awareness and COM as an interaction effect which is a higher-order construct that affects the purchase intention of low-involvement products such as toothpaste. This position is based on well-known brands from developed countries that produce low-involvement products such as toothpaste in developing countries. Therefore, this study positions that the interaction between COM and brand awareness has a positive effect on the youth purchase intention of toothpaste.

H1: Interaction effect of the country of manufacture and brand awareness have a positive effect on the consumer's intention to purchase toothpaste.

\section{Price}

The price is the amount of money that a consumer has to pay to get a product or service (Kotler \& Armstrong, 2012) This is one of the most significant information cues (Lichtenstein, Ridgway \& Netemeyer 1993). 
The price has objective extrinsic characteristics and a subjective intrinsic representation resulting from consumers' understanding of the price (Dodds, Monroe \& Grewal 1991). The objective price is the real price of the product while the perceived price is the consumer's general perception of the superiority of the product (Zeithaml, 1988). The perceived price is the price set by the consumer. It is not the actual price of the good. This is because consumers do not always remember the actual price of the product. The consumer, therefore, sees the price through a subjective perception and realises that it is either "expensive" or "cheap" (Zeithaml, 1988). The price plays two different roles. It can be an indicator of product quality or an indicator of the amount needed to make sacrifices on the purchase of a product (Dodds, et al 1991). If the price of a good is high, it can be considered high quality, leading to greater purchase intention. On the other hand, if the commodity price is high, the amount that the consumer must sacrifice to obtain the commodity is high, resulting in less purchase intention (Dodds \& Monroe, 1985). In this study, the perceived price of toothpaste is used to evaluate the consumer's intention to purchase toothpaste. The perceived price plays both a negative and positive role, making it a complicated stimulant.

Value-conscious consumers pay attention to low prices and product quality. They rate and compare the prices of different product brands to get their money's worth (Sharma, 2011). Smart consumers are often more positive about advertising and do not believe that a reduced-price equals lower product quality (Lichtenstein et al., 1993). Instead, they see the advertising price as a way to save money (Garretson et al., 2002). Consumers from developing markets have lower purchasing power, higher price elasticity of demand, and a greater propensity to purchase through family savings. Therefore, they are more value-conscious and price-sensitive (Brouthers \& Xu, 2002). The results of Sharma's study (2011) have shown that consumers' purchase intention is significantly influenced by value awareness, especially when consumers come from a developing market. Therefore, the price can be a factor that would also affect the consumer's intention to purchase toothpaste. The following hypothesis is stated:

H2: The price will have a positive effect on consumer's purchase intention for toothpaste. 


\section{Packaging}

Packaging may be referred to as an extrinsic element of a product, it is not part of the physical product itself, but it is still related to the product (Deliva \& Parmar, 2012). The goal is to highlight the uniqueness and differences of a product. These unique features are often used to assess product quality (Silayoi \& Speece, 2004). If the packaging is of high quality, it is considered that the product is of high quality, and conversely, if the packaging is of low quality, the product is of low quality (Silayoi \& Speece, 2004). In marketing, packaging is viewed as a means of communicating product information to consumers during sales (Prendergast \& Pitt, 1996) and plays a role of sales assistant who informs consumers about product qualities and benefits. Therefore, the packaging has been termed a "silent salesman" (Ampuero \& Vila, 2006).

The study by Olawepo \& Ibojo (2015) states that packaging has a significant effect on consumers' purchase intention, with consumers agreeing that product packaging attracts them and influences their purchase intention. Besides, Zekiri and Hasani (2015) show that packaging help consumers to simplify consumers' purchasing decisions. Therefore, the packaging may influence the consumer's intention to purchase toothpaste, from which the following hypothesis has been derived.

H3: Packaging has a positive effect on consumer's purchase intention of toothpaste.

\section{Research Framework}

Based on the literature review above, this study proposes a research framework for factors that influence the purchase intention of toothpaste in young adults. Figure 1 describes the research framework and the hypothetical relationship. 


\section{Figure 1. Research Framework}

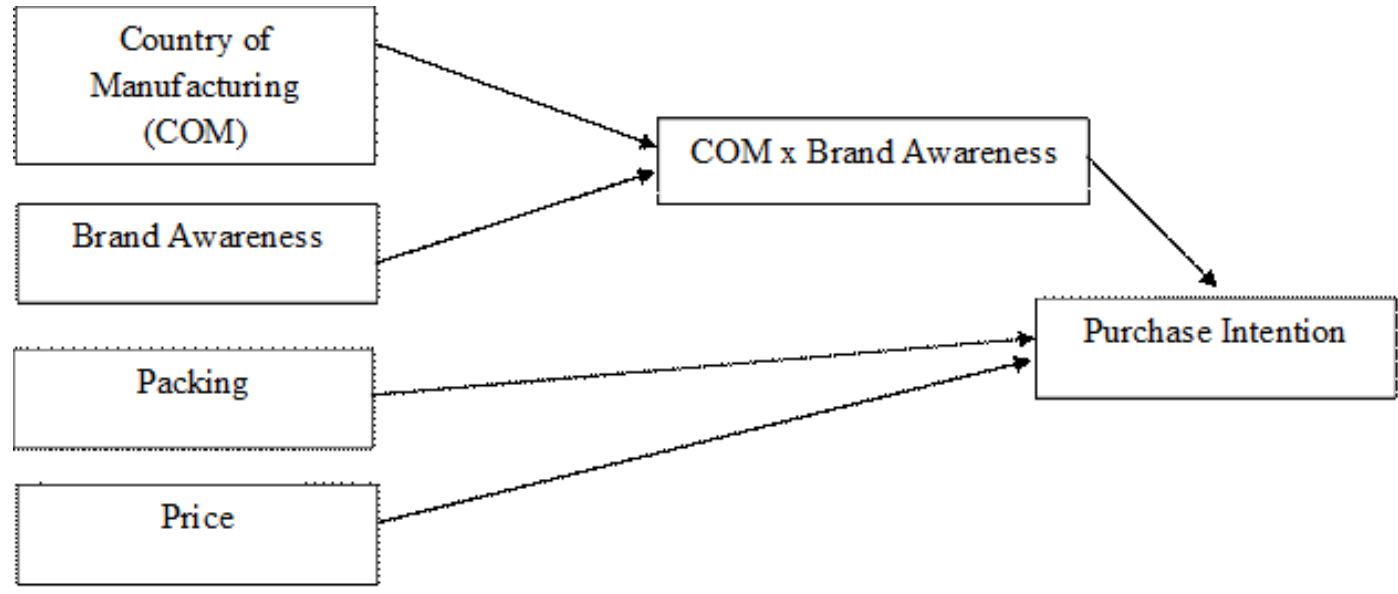

\section{Research Methodology}

This study focuses on young adults in Klang Valley, Malaysia between the ages of 18 and 30. Convenient and snowballing methods are used to obtain data collection. A total of 389 useable surveys are collected out of the 430 surveys distributed. These respondents are a consumer segment with significant current and future purchasing power that attracts the attention of marketing efforts (Ma, Littrell \& Niehm 2012). The sample consist of $63 \%$ Female and $36.2 \%$ males. Majority of the respondents are 20-24 years old (70.7\%), 25 and above (21.1\%) and $8.2 \%$ were 20 years old. Most of the respondents are earning above RM1000.

The measurement items are all taken from the existing literature. The 7-point Likert scale was used with $1=$ "Strongly Disagree" and $7=$ "Strongly Agree". The units of measurement for the manufacturing country were adapted from Hoang, Phuong, Ho \& Chi (2017), and brand awareness adapted from Rubio, Oubina \& Villasenor (2013). The measurement items of packaging were adapted from Salem (2018) and the price measurement scales are adapted from Lichtenstein, et al. (1993). Lastly, the purchase intention measurements were adapted from Cheng, $\mathrm{Fu}, \& \mathrm{Tu}$ (2011). 


\section{Results}

The collected data were analysed using SmartPLS Version 3.2.7. Firstly, this study used SmartPLS to generate measurement model results; followed by the structural model examination. All the assessment adhered to Hair Hult, Ringle, \& Sarstedt (2017).

\section{Measurement Model Analysis}

The outer loading of the measure and the average variance extracted (AVE) should be taken into account when evaluating the convergent validity of reflective constructs. The general rule for outer loading is that it should be 0.708 or higher and if the outer loading of an item is between 0.4 and 0.7, this should be considered for elimination (Hair, et al., 2017). As shown in Table 1, several items should be removed with an outer loading between 0.4 and 0.7 , but only two of the highlighted items (PRICE1 and PRICE6) are removed. Some items of lower than 0.708 have been retained because the construct has attained minimum AVE value of 0.5 (Ramayah, Cheah, Chuah, Ting \& Memon, 2018). Table 1 shows the results of the measurement model when items PRICE1 and PRICE6 are deleted.

The AVE Price increased after the elimination of the two items and it is shown in Table 1. The overall AVE score has exceeded the 0.5 threshold. Hence, there was no further items elimination. Analysis of the internal consistency of constructs composite reliability (CR) showed that all were well above the acceptable value of 0.7 (Hair et al., 2017). The composite reliability (CR) values range from 0.87 to 0.94 , which is considered satisfactory (Hair et al., 2017). Hence, all the constructs have adequate internal consistency and convergent validity.

This study evaluates discriminant validity by using the heterotraitmonotrait ratio (HTMT) (Henseler, Ringle, \& Sarstedt, 2015). The HTMT value for all construct pairs must not be higher than 0.85 (Hair, et al., 2017). As shown in Table 2, the total HTMT value of all pairs for this study is below 0.85 ; therefore, they all have discriminant validity. 
Table 1. Reflective Measurement Model: Factor Loadings, CR and AVE

\begin{tabular}{|c|c|c|c|c|c|}
\hline Construct & Item & $\begin{array}{c}\text { Outer } \\
\text { Loading }\end{array}$ & AVE & $\begin{array}{l}\text { Composite } \\
\text { Reliability }\end{array}$ & $\begin{array}{c}\text { Cronbach's } \\
\text { Alpha }\end{array}$ \\
\hline \multirow[t]{5}{*}{ Country of Manufacture } & COM1 & 0.855 & 0.699 & 0.920 & 0.891 \\
\hline & COM2 & 0.888 & & & \\
\hline & $\mathrm{COM} 3$ & 0.876 & & & \\
\hline & COM4 & 0.761 & & & \\
\hline & COM5 & 0.792 & & & \\
\hline \multirow[t]{5}{*}{ Brand Awaren ess } & BA1 & 0.691 & 0.574 & 0.870 & 0.821 \\
\hline & BA2 & 0.810 & & & \\
\hline & BA3 & 0.718 & & & \\
\hline & BA4 & 0.828 & & & \\
\hline & BA5 & 0.732 & & & \\
\hline \multirow[t]{8}{*}{ Packaging } & PKG1 & 0.675 & 0.506 & 0.891 & 0.865 \\
\hline & PKG2 & 0.681 & & & \\
\hline & PKG3 & 0.665 & & & \\
\hline & PKG4 & 0.695 & & & \\
\hline & PKG5 & 0.788 & & & \\
\hline & PKG6 & 0.771 & & & \\
\hline & PKG7 & 0.673 & & & \\
\hline & PKG8 & 0.732 & & & \\
\hline \multirow[t]{5}{*}{ Price } & PRICE2 & 0.762 & 0.634 & 0.896 & 0.857 \\
\hline & PRICE3 & 0.803 & & & \\
\hline & PRICE4 & 0.797 & & & \\
\hline & PRICE5 & 0.794 & & & \\
\hline & PRICE7 & 0.823 & & & \\
\hline \multirow[t]{3}{*}{ Purchase Intention } & PI1 & 0.911 & 0.839 & 0.940 & 0.905 \\
\hline & PI2 & 0.923 & & & \\
\hline & PI3 & 0.914 & & & \\
\hline
\end{tabular}

Table 2. Discriminant validity of the measurement model: Heterotrait-Monotrait (HTMT) criterion (2015)

\begin{tabular}{lccccc} 
& BA & COM & PKG & PRICE & PI \\
\hline BA & & & & & \\
COM & 0.212 & & & & \\
PKG & 0.337 & 0.253 & & \\
PRICE & 0.229 & 0.245 & 0.451 & & \\
PI & 0.186 & 0.246 & 0.281 & 0.355 & \\
\hline
\end{tabular}

Note: HTMT $<0.85$ (Kline, 2011)

$\mathrm{BA}=\mathrm{Brand}$ Awareness; $\mathrm{COM}=$ Country of Manufacture; $\mathrm{PKG}=$ Packaging; $\mathrm{PI}=$ Purchase Intention 


\section{Assessment of Formative Second-Order Constructs}

Table 3 illustrates the evaluation of formative second-order constructs. The interaction of country of origin and brand awareness (COMxBA, represented by INTE) of collinearity issues were evaluated. Table 3 shows the values of the variance inflation factor (VIF) for each of the formative constructs that are below the threshold of 3.3 (Hair et al 2017), indicating that collinearity did not reach critical levels in any of the formative constructs and that these constructs are unique and evaluate different aspects of the perceived quality factors. Therefore, estimating the partial least squares path model is not a problem.

\section{Table 3. Collinearity Assessment for Formative Second-Order Construct}

\begin{tabular}{ll}
\hline & INTE \\
\hline Brand Awareness & 1.035 \\
Country of Manufacture & 1.035 \\
\hline
\end{tabular}

* INTE=interaction COMxBA

Subsequently, the significance and relevance of the outer weights of the formative constructs were also evaluated. Table 4 shows the bootstrapping results, with the weights and path coefficient given for each of the formative constructs (Hair et al., 2011). The bootstrapping results show that all formative indicators are significant.

\section{Table 4. Path Co-Efficient Assessment for Outer Weights on Second-Order Constructs}

\begin{tabular}{lcccc}
\hline & Direct Effect $(\beta)$ & Standard Error & T-statistic & P-value \\
\hline $\mathrm{BA} \rightarrow \mathrm{INTE}$ & 0.532 & 0.175 & $3.033^{*} k_{k}$ & 0.003 \\
$\mathrm{COM} \rightarrow \mathrm{INTE}$ & 0.755 & 0.143 & $5.280^{*}$ * & 0.000 \\
\hline
\end{tabular}

${ }_{* * *} \mathrm{p}<0.01,{ }^{*} \mathrm{p}<0.05$ (one-tailed)

$\mathrm{BA}=\mathrm{Brand}$ Awareness; $\mathrm{COM}=$ Country of Manufacture, $\mathrm{INTE}=$ interaction effect $\mathrm{COM}$ and BA $(\mathrm{COMxBA})$ 


\section{Goodness of Fit (GOF)}

The Standard Root Mean Square Residual (SRMR) values are 0.095 and 0.095 indicating that the model has a considerably good fit for saturated model and estimated model. A value less than 0.10 or of 0.08 (in a more conservative version, $\mathrm{Hu} \&$ Bentler, 1998) is considered a good fit (Ramayah et al., 2018). Henseler et al. (2015) introduced the SRMR as a goodness of fit measures for PLS-SEM that can be used to avoid model misspecification. SmartPLS provides bootstrap-based inference statistics of the SRMR criteria (Ramayah et al., 2018).

\section{Assessment of Structural Model}

Table 5 shows the results of the lateral collinearity test of the model. All inner VIF values for each construct are below the limit of 3.3 (Hair et al 2017) which indicates that lateral multicollinearity is not a problem.

\section{Table 5. Collinearity Assessment}

\section{PI}

INTE 1.148

PKG

PRICE

INTE=COMxBA; PKG=Packaging; PI=Purchase Intention

Bootstrapping is used to analyse structural models. The bootstrapping analysis results for 389 are shown in Figure 2.

The strength and significance of the hypothetical relationship between the constructs can be understood by the results of the path coefficient (Sarstedt, Ringle, Smith, Reams \& Hair 2014). The path coefficient is significant if the t-value is higher than the critical value (Hair, et al., 2017). All $t$-values of the path coefficient exceeded the critical value; therefore, all three hypotheses are supported, as shown in Table 6. 


\section{Figure 2. Structural Model}

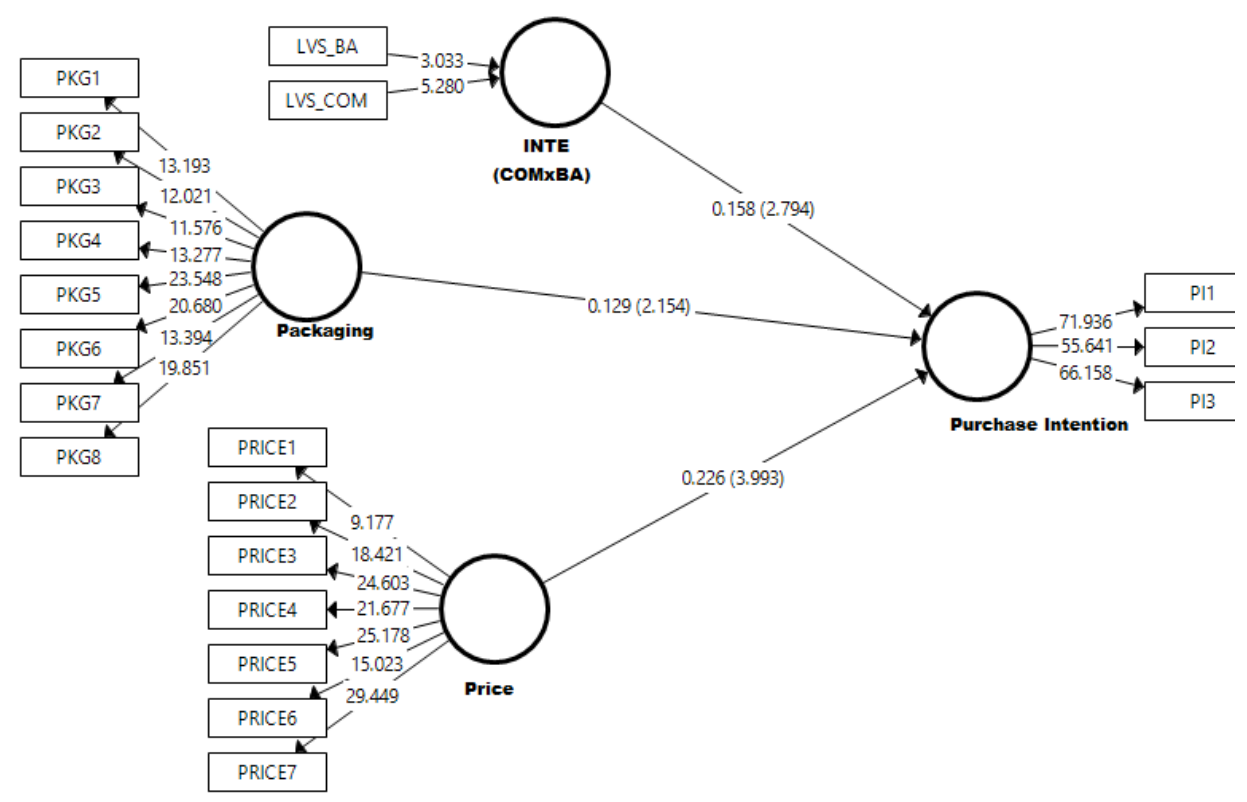

\section{Table 6. Path Co-Efficient Assessment}

\begin{tabular}{lccccc}
\hline & $\begin{array}{c}\text { Direct Effect } \\
(\beta)\end{array}$ & $\begin{array}{c}\text { Standard } \\
\text { Error }\end{array}$ & T-statistic & P-value & Decision \\
\hline $\mathrm{NTE} \rightarrow$ PI & 0.158 & 0.057 & $2.794^{* *}$ & 0.005 & Supported \\
$\mathrm{PKG} \rightarrow$ PI & 0.129 & 0.060 & $2.154^{* *}$ & 0.032 & Supported \\
$\mathrm{PRICE} \rightarrow$ PI & 0.226 & 0.057 & $3.993^{*} *$ & 0.000 & Supported \\
\hline
\end{tabular}

Note: ${ }^{*}{ }^{*} \mathrm{p}<0.01,{ }^{*} \mathrm{p}<0.05$ (one-tailed)

$\mathrm{INTE}=\mathrm{COMxBA} ; \mathrm{PKG}=$ Packaging; $\mathrm{PI}=$ Purchase Intenti on

The coefficient of determination ( $R^{2}$ value) evaluates the predictive accuracy of the model. As shown in Table 7, the purchase intention of $\mathrm{R}^{2}$ is 0.151 , indicating that the combined effect of country of manufacture and brand awareness, packaging and price account for $15.1 \%$ of the purchase intention of toothpaste. 
Following that, the predictive relevance $\left(Q^{2}\right)$ is evaluated. Table 7 shows the $\mathrm{Q}^{2}$ values for the purchase intention of toothpaste $(0.112)$ which is greater than 0 indicating that the model has sufficient relevance for the prediction. The effect sizes of the exogenous variables on the endogenous variable, where the interaction of country of origin and brand awareness $\left(f^{2}=0.026\right)$ and price $\left(f^{2}=0.048\right)$ has a small effect size and packaging $\left(f^{2}=0.015\right)$ has a trivial effect on the purchase intention of toothpaste.

Table 7: Determination of Co-effecient $\left(\mathbf{R}^{2}\right)$, Effect size $\left(\mathbf{f}^{2}\right)$ and Predictive Relevance $\left(\mathbf{Q}^{2}\right)$

\begin{tabular}{ccccc}
\hline & $\begin{array}{c}\text { Determination } \\
\text { Co-efficient }\end{array}$ & $\begin{array}{c}\text { Predictive } \\
\text { Relevance }\end{array}$ & Effect Size $\left(f^{2}\right)$ & \\
\hline$R^{2}$ & $Q^{2}$ & $P I$ & Effect Size \\
\hline PI & 0.151 & 0.112 & & \\
INTE & & & 0.026 & Small \\
PKG & & 0.015 & Trivial \\
PRICE & & 0.048 & Small \\
\hline
\end{tabular}

$* \mathrm{NTE}=\mathrm{COMxBA}$; PKG=Packaging; PI=Purchase Intention

Importance and Performance Matrix (IPMA)

The importance and performance matrix (IPMA) is useful to extend the results of basic PLS-SEM results using the latent variable score (Hair et al., 2017). This method is particularly useful in the analysis of key constructs such as the interaction effect of manufacturing country and brand awareness (Ringle \& Sarstedt 2016). IPMA compares the overall effects (importance) of the structural model and the average values of the assessments (performance) of the latent variables of a particular endogenous construct to highlight important areas for improving the management activities. (Hair et al, 2017). 
Figure 3 and Table 8 show that the IPMA purchase intention shows that both COM and brand awareness variables, considered as an interaction construct (INTE), are the important constructs compared to the price and packaging construct. The price is already in high performance, but INTE is at the lowest performance of 51.879. The significance of this construct with a total effect of 0.331 is particularly high. Therefore, increasing the performance of INTE by one unit from 51.879 to 52.879 would increase the performance of the purchase intention (PI) by 0.331 points from 60.586 (Figure 3) to 60.917. Therefore, if managers want to enhance the performance of the purchase intention, it should be paramount to improve the performance of the INTE captured aspects (i.e., Manufacturing Country (COM) and Brand Awareness (BA)), as this construct has the highest importance, but relatively low-performance; the aspects of price and packaging are the second and third priorities. Therefore, managers/marketers should not focus much on packaging variables as this may overwhelm the business if the purchase intention of consumers is affected.

Figure 3. Importance and Performance Map

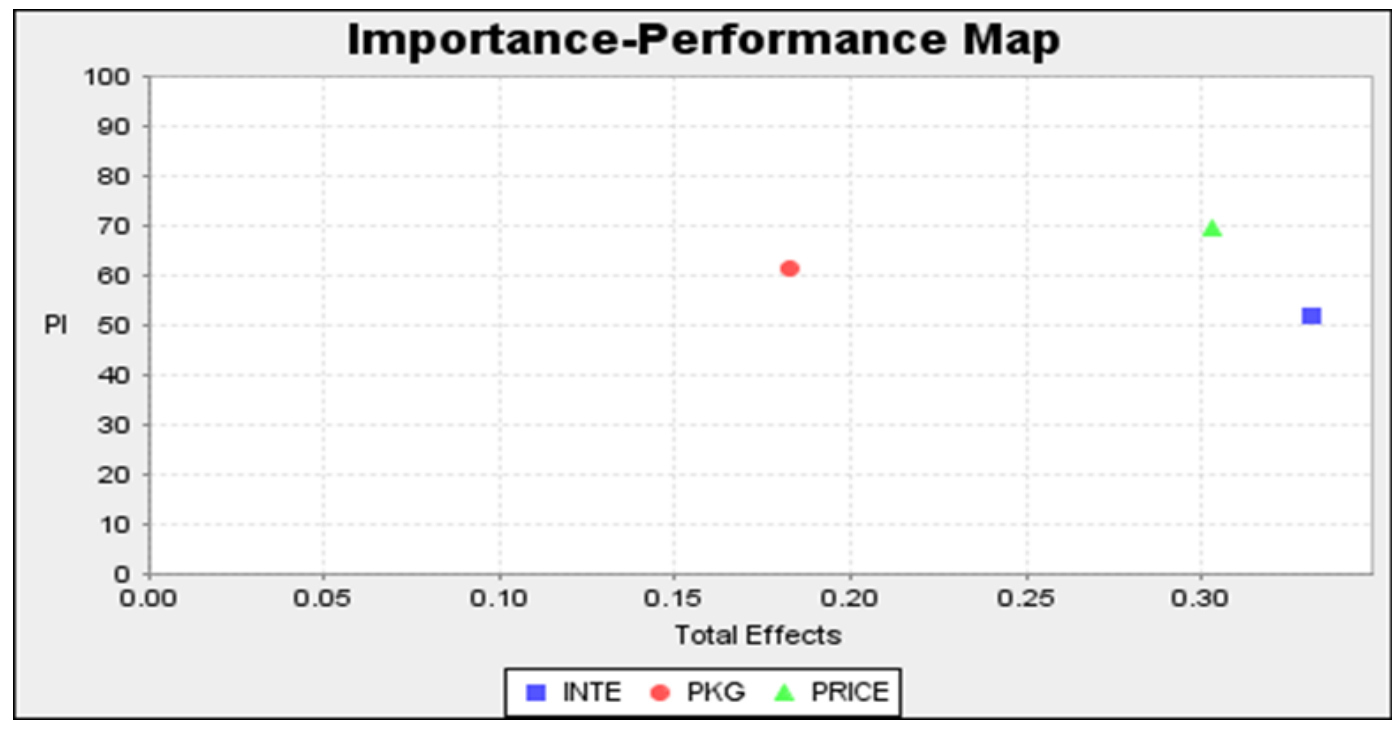


Table 8. IPMA Result

\begin{tabular}{lcc}
\hline Construct & Importance (Total Effect) & Performance (Index Value) \\
\hline INTE & 0.331 & 51.879 \\
Packaging & 0.182 & 61.330 \\
Price & 0.303 & 69.434 \\
\hline
\end{tabular}

$* \mathrm{NTE}=\mathrm{COMxBA}$

Figure 4. Path Model: Importance Performance Map Analysis

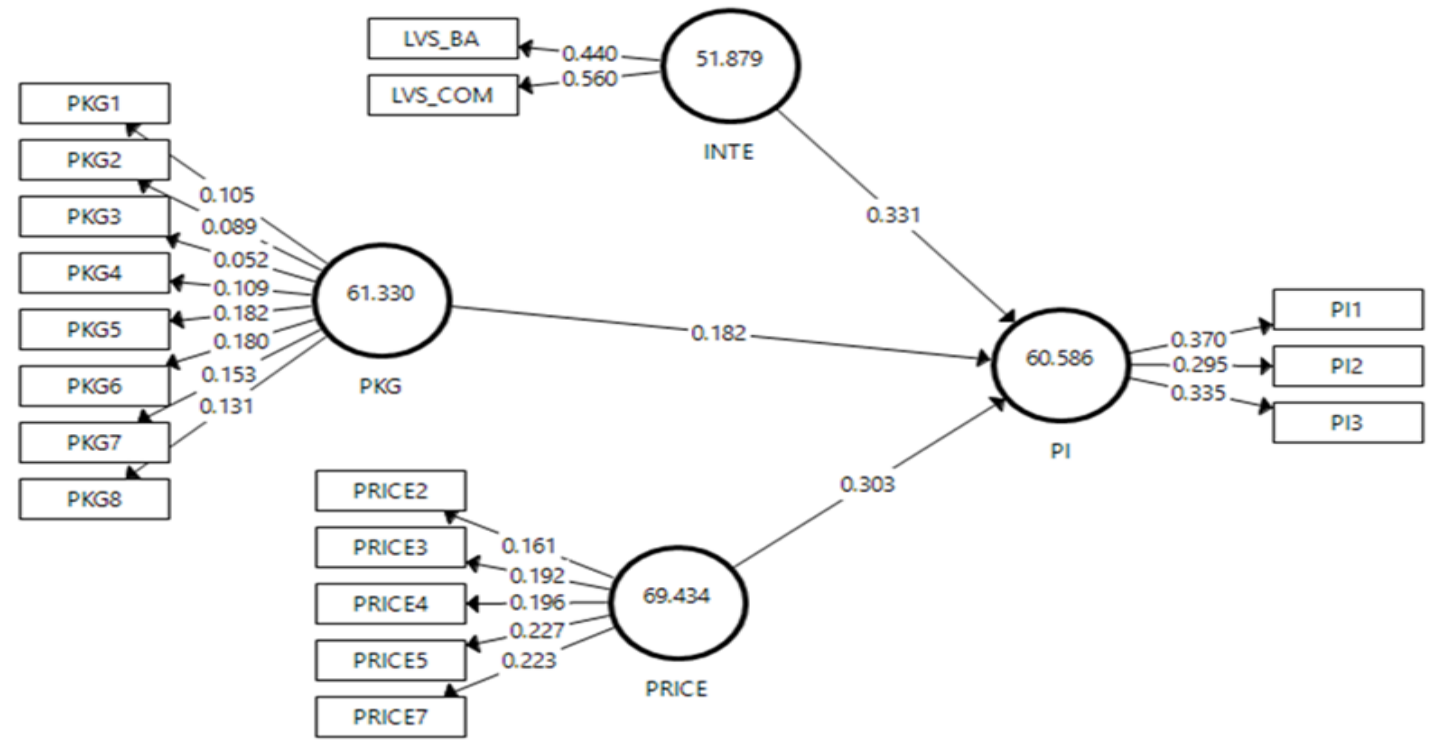

\section{Discussion \& Implication}

The result of this study supports Hypothesis 1 (H1), which states that the country of manufacture (COM) and brand awareness (BA) have a positive effect on the consumer's intention to purchase toothpaste. This is in line with the results of Parkvithee \& Miranda (2012), in which the interaction between COM and BA has a direct and significant relationship 
with the consumer's intention to purchase. In summary, the purchase intention of young adults for toothpaste is significantly dependent on the nation production of toothpaste and brand awareness. Also, the interaction of $\mathrm{COMxBA}$ on IPMA analysis indicates the lowest performance, meaning that there is a significant need for improvement as COMxBA makes the underlying construct more relevant to management and policy measures than other factors. As such, it may be useful because when a particular product is produced in an unfavourable country of manufacture, marketers may have to market their product in a way that it does not emphasize on the products made in the country but focuses on creating brand awareness. The visibility of the COM and the brand, as well as their interaction, are what guide consumers' opinions about the country and the products made in that country as a whole. In other words, the interplay of COM and brand awareness are important factors that raise concerns about the country of origin of the product and, generally, product evaluation. COM has a less favourable image, and if brand awareness is high, marketers may need to find ways to focus on the brand perspective. If COM has a favourable image, the focus may be on the land that makes the product the new brand. This will stimulate purchase intention which underpins this construct and is particularly relevant to management and policy actions.

Also, Hypothesis 2 is supported, in which the price has a positive effect on the consumer's intention to purchase toothpaste. The result of this study is in line with the findings of Sharma (2011) and Ang, Cheng, Lim \& Tambyah (2001), with consumers' purchase intention influenced by their value awareness. Therefore, it is concluded that young adults intend to purchase the toothpaste when the price-performance ratio of the toothpaste is low and of acceptable quality. Therefore, manufacturers of low-involvement products must realistically assess their products to represent the quality and value of the product when consumers are willing to purchase for the given price due to the value that they are expecting to receive for the given price.

Finally, the result of the present study supports Hypothesis 3 (H3), which states that packaging has a positive effect on consumers' intention to purchase toothpaste. The results of this study are in line with the findings of Shafiq, Raza and Zia-ur-Rehman (2011), as well as Hussain, Ali, Ibrahim, Noreen and Ahmad (2015) that there is a significant relationship between 
the purchase intention and packaging. Therefore, it can be concluded that toothpaste packaging is attractive, and consumers are more attracted to it which increases their purchase intention for toothpaste. Marketing professionals should emphasise and improve two items of the package. the visual items (i.e., graphics, colour, size, shape, material) and the verbal items (i.e., product information, manufacturer, country of origin, brand) to attract consumers to purchase (Kuvykaite et al., 2009).

Consumers generally value developing country goods in a discriminatory way because of people's past beliefs (Rezvani et al., 2012). As a result, products made from developing countries often faced unjust evaluation problems. Findings of this study showed that all of the factors have an effect on the purchase intention of consumers. Besides that, this study has contributed to the Cue Utilisation Theory, which emphasised on the significance of the manufacturer's country of origin and brand awareness, as well as price and packaging as vital factors that acts as a potential signal to motivate consumers to purchase a low-involvement product (i.e. toothpaste).

\section{Limitations and Recommendation}

This study has limitations that should be considered. Firstly, the low involvement of the products selected for this study is toothpaste. Therefore, the results of this study cannot be generalised for all goods with low involvement. The extrinsic cues chosen for this study may not be important for other low-involvement goods. Future research should probably focus on a variety of low-involvement products to better understand how the interaction of $\mathrm{COM}$ and $\mathrm{BA}$ affects consumers and the purchase intention of low-involvement goods. Also, the coefficient of determination of this study shows that the predictive accuracy of the model is weak. This shows that there may be other independent variables that can better explain the dependent variable. This study included only four independent variables that are extrinsic (COM, brand awareness, price and packaging). There may be other extrinsic indications that may better explain consumer purchase intention for toothpaste. Also, products have an intrinsic cue that is not included in this study. Therefore, future research should include both 
extrinsic (e.g., brand name, price, packaging, advertising or corporate image) and intrinsic cues (e.g., quality of ingredients or ingredients used, colour, taste, odour, appearance) (Idoko, Nkamnebe, Ireneus, \& Okoye, 2013) to better understand their effect on the consumer's intention to purchase toothpaste or other low-involvement products.

\section{Conclusion}

The focus of this research is to study the interaction effect between country of manufacture and brand awareness, price and packaging among young adults in Malaysia, who intend to purchase toothpaste. The results, discussions and implications suggest that manufacturers of lowinvolvement goods should use the COMxBA information with caution, as an unfavourable country of manufacture may focus on brand awareness or promote consumers' purchase intention.

\section{References}

1. Aaker, D. (1991). Managing brand equity. New York: The Free Press.

2. Acebron, L., \& Dopico, D. (2000). The importance of intrinsic and extrinsic cues to expected and experienced quality: An empirical application for beef. Food Quality and Preference, 11(3), 229-238.

3. Ampuero, O., \& Vila, N. (2006). Consumer perceptions of product packaging. Journal of Consumer Marketing, 23(2), 100-112.

4. Ang, S., Cheng, P., Lim, E., \& Tambyah, S. (2001). Spot the difference: Consumer responses towards counterfeits. Journal of Consumer Marketing, 18(3), 219-235.

5. Bayraktar, A., Uslay, C., \& Ndubisi, N., (2015). The role of mindfulness in response to product cues and marketing communications. International Journal of Business Environment, 7(4), 347-372.

6. Brouthers, L.E., \& Xu, K. (2002). Product stereotypes, strategy and performance satisfaction: The case of Chinese exporters. Journal of International Business Studies, 33(4), 657-677. https://doi.org/10.1057/palgrave.jibs.8491038.

7. Bruwer, J., Chrysochou, P., \& Lesschaeve, I. (2017). Consumer involvement and knowledge influence on wine choice cue utilisation. British Food Journal, 119(4), 830-844.

8. Cheng, S., Fu, H., \& Tu, L. (2011). Examining customer purchase intention for counterfeit products based on modified theory of planned behaviour. International Journal of Humanitites and Social Science, 1(10), 278-284. 
9. Chinen, K., Jun, M., \& Hampton, G. (2000). Product quality, market presence, and buying behaviour: Aggregate images of foreign products in the US. Multinational Business Review, 8 (1), 29-38.

10. Dawar, N., \& Parker, P. (1994). Consumers' use of brand name, price, physical appearance and retailer reputation as signals of product quality. Journal of Marketing, $58(2), 81-95$.

11. de Run, E., Chan, A., \& Khalique, M. (2012). Attitudinal and behavioral response to coo cues for low involvement product. International Journal of Research Studies in Malaysia, 1(2), 3-14.

12. Degoma, A., \& Shetemam, E. (2014). The effect of country of origin image on purchase intention: A case study on Bahir Dar University instructors. Journal of Accounting \& Marketing, 3(1), 1-5.

13. Deliva, M., \& Parmar, B. (2012). Role of packaging on consumer buying behavior-Patan District. Global Journal of Management and Business Research, 12(10), 49-68.

14. Dharmadasa, P., \& Chanaka, W. (2017). Impact of country of origin effect (COE) on consumer purchase intentions. Arabian Journal of Business and Management Review, $7(4), 1-5$.

15. Dodds, W., \& Monroe, K. (1985). The effect of brand and price information on subjective product evaluations. Advances in Consumer Research, 12, 85-90.

16. Dodds, W., Monroe, K., \& Grewal, D. (1991). Effect of price, brand, and store information on buyers' product evaluation. Journal of Marketing, 28(3), 307-319. https://doi.org/10.2307/3172866.

17. Fishbein, M., \& Ajzen, I. (1975). Belief, attitude, intention and behavior: An introduction to theory and research. Addison-Wesley, Reading, MA.

18. Fetscherin, M., \& Toncar, M. (2010). The effects of the country of brand and the country of manufacturing of automobiles: An experimental study of consumers' brand personality perceptions. International Marketing Review, 27(2), 164-178. doi.org/10.1108/02651331021037494.

19. Garretson, J., Fisher, D., \& Burton, S. (2002). Antecedents of private label attitude and national brand promotion attitude: Similarities and differences. Journal of Retailing, 78(2), 91-99. https://doi.org/10.1016/S0022-4359(02)00071-4.

20. Ghazali, M., Othman, M. S., Yahya, A. \& Ibrahim, M. S. (2008). Products and Country of Origin Effects: The Malaysian Consumers' Perception. International Review of Business Research Papers, 4(2), 91-102.

21. Gow, C.X., Wong, S.C., \& Lim, C.S. (2019). Effect of output quality and result demonstrability on Generation Y's behavioural intention in adopting mobile health applications. Asia-Pacific Journal of Management Research and Innovation, 1(11), doi. 10.1177/2319510X19872597.

22. Hair, J., Ringle, C., \& Sarstedt, M. (2011). PLS-SEM: Indeed a silver bullet. Journal of Marketing Theory and Practice, 19, 139-151. https://doi.org/10.2753/MTP10696679190202.

23. Hair, J., Hult, G., Ringle, C., \& Sarstedt, M. (2017). A Primer on Partial Least Squares Structural Equation Modeling (PLS-SEM) (2nd ed. ). Los Angeles: Sage Publications.

24. Han, C.M. (1989). Country image: Halo or summary construct? Journal of Marketing Research, 26(2), 222-229. doi:10.1177/002224378902600208. 
25. Helm, R., \& Mark, A. (2007). Implications from cue utilisation theory and signalling theory for firm reputation and the marketing of new products. International Journal of Product Development, 4(3-4), 396-411. https://dx.doi.org/10.1504/IJPD.2007.012504.

26. Henseler, J., Ringle, C., \& Sarstedt, M. (2015). A new criterion for assessing discriminant validity in variance-based structural equation modeling. Journal of the Academy of Marketing Science, 43, 115-135. https://doi.org/10.1007/s11747-014-0403-8.

27. Hoang, T., Phuong, V., Ho, P., \& Chi, N. (2017). Effect of country of origin and product feature on consumer purchase intention: A study of imported powder milk. Academy of Marketing Studies Journal, 21(1), 1-19.

28. Hoyer, W., \& Brown, S. (1990). Effects of brand awareness on choice for a common, repeat-purchase product. Journal of Consumer Research, 17(2), 141-148. http://www.jstor.org/stable/2626806.

29. Hsin, K., Ren, H., \& Ya, T. (2009). The impact of brand awareness on consumer purchase intention: The mediating effect of perceived quality and brand loyalty. The Journal of International Management Studies, 4(1), 135-144.

30. Hu, L., \& Bentler, P.M. (1998). Fit indices in covariance structure modelling: Sensitivity to underparameterized model misspecification. Psychological Methods, 3(4), 424-453.

31. Hussain, S., Ali, S., Ibrahim, M., Norree, A., \& Ahmad, S.F. (2015). Impact of product packaging on consumer perception and purchase intention. Journal of Marketing and Consumer Research, 10, 1-10.

32. Kala, D., \& Chaubey, D. (2016). Country-of-origin effect and consumers' buying behaviour: An evidence from Indian market. Management Convergence, 7(1), 47-59.

33. Kaynak, E., Kucukemiroglu, O., \& Hyder, A.S. (2000). Consumers' country-of-origin (COO) perceptions of imported products in a homogenous less-developed country. European Journal of Marketing, 34, 1221-1241.

34. Keller, K. (1993). Conceptualizing, measuring, and managing customer-based brand equity. Journal of Marketing, 57(1), 1-22.

35. Kotler, P., \& Armstrong, G. (2012). Principles of marketing (14th ed.). Boston: Pearson Prentice Hall.

36. Kuvykaite, R., Dovaliene, A., \& Navickiene, L. (2009). Impact of package elements on consumer's purchase decision. Economics and management, 14, 441-447.

37. Idoko, E.C., Nkamnebe, A.D., Ireneus, N.C., \& Okoye, V.I. (2013). Effects of intrinsic and extrinsic product cues on consumers' purchase intention: A study of alcoholic beverage consumers in a developing country metropolitan city. Researchers World, 4(3), 1-11.

38. Lai, P.C. \& Lim, C.S. (2019), The effects of efficiency, design and enjoyment on single platform e payment. Research in Business and Management, 6(2), 1-16

39. Lee, J., Lee, B., \& Lee, W. (2013). Country-of-origin fit's effect on consumer product evaluation in cross-border strategic brand alliance. Journal of Business Research, 66, 354-363.

40. Lew, S., \& Sulaiman, Z. (2013). Consumer purchase intention toward products made in Malaysia vs. made in China: A conceptual paper. Procedia - Social and Behavioral Sciences, 37-45.

41. Lichtenstein, D., Ridgway, N., \& Netemeyer, R. (1993). Price perceptions and consumer shopping behavior: A field study. Journal of Marketing Research, 30(2), 234-245. https://doi.org/10.2307/3172830. 
42. Lim, C.S., \& Omar, N.A. (2019). Social intention model: The effect of self and social facets on students' social intention. International Journal of Economics and Management, 13(1), 217-230.

43. Lin, L., \& Chen, C. (2006). The influence of the country-of-origin image, product knowledge and product involvement on consumer purchase decisions: An empirical study of insurance and catering services in Taiwan. Journal of Consumer Marketing, 23(5), 248-265.

44. Ma, J.Y., Littrell, M.A., \& Niehm, L. (2012). Young female consumers' intentions toward fair trade consumption. International Journal of Retail \& Distribution Management, 40(1), 41-63. HYPERLINK "https://doi.org/10.1108/09590551211193595"|o"DOI: https://doi.org/ 10.1108/09590551211193595" https://doi.org/10.1108/09590551211193595

45. Mordor Intelligence. (2019). Asia-Pacific Toothpaste Market. Retrieved from https:/www.mordorintelligence.com/industry-reports/asia-pacific-toothpaste-market

46. Motale, M., \& Dhurup, M. (2016). Walking the talk in the sport footwear industry: A generation $\mathrm{Y}$ cohort analysis of consumer based brand equity dimension and purchase intention. International Journal of Business and Management , 8(2), 102-120.

47. Olawepo, G., \& Ibojo, B. (2015). The relationship between packaging and consumers purchase intention: A case study of Nestlé Nigeria Product. International Business and Management, 10(1), 72-81.

48. Ozretic, D., Skare, V., \& Krupka, Z. (2007). Assessments of country of origin and brand cues in evaluating a Croatian, western and eastern European food product. Journal of Business Research, 60(2), 130-136.

49. Parkvithee, N., \& Miranda, M. (2012). The interaction effect of country-of-origin, brand equity and purchase involvement on consumer purchase intentions of clothing labels. Asia Pacific Journal of Marketing and Logistics, 24(1), 7-22. doi. 10.1108/13555851211192678

50. Pezoldt, K., Michaelis, A., Roschk, H., \& Geigenmueller, A. (2014). The differential effects of extrinsic and intrinsic cue-utilization in hedonic product consumption-An empirical investigation. Journal of Business and Economics, 5(8), 1282-1293.

51. Prendergast, G., Tsang, S., \& Chan, N. (2010). The interactive influence of country of origin of brand and product involvement on purchase intention. Journal of Consumer Marketing, 27(2), 180-188.

52. Prendergast, P., \& Pitt, L. (1996). Packaging, marketing, logistics and the environment: are there trade-offs? International Journal of Physical Distribution \& Logistics Management, 26(6), 60-72.

53. Rao, A.R., \& Monroe, K.B. (1988). The moderating effect of prior knowledge on cue utilisation in product evaluations. Journal of Consumer Research, 15, 253-264.

54. Ramayah, T., Cheah, J., Chuah, F., Ting, H., \& Memon, M.A. (2018). Partial least squares structural equation modeling (PLS-SEM) using SmartPLS 3.0: An updated and practical guide to statistical analysis (2nd ed.) Singapore: Pearson.

55. Rezvani, S., Javadian Dehkordi, G., Sabbir Rahman, M., Fouladivanda, F., Habibi, M., \& Eghtebasi, S. (2012). A conceptual study on the country of origin effect on consumer puchase intention. Asian Social Science, 8(12), 205-215.

56. Ringle, C.M., \& Sarstedt, M. (2016), Gain more insight from your PLS-SEM results: The importance performance map analysis. Industrial Management \& Data Systems, 116(9), $1-37$. 
57. Rubio, N., Oubina, J., \& Villasenor, N. (2013). Brand awareness - brand quality inference and consumer's risk perception in store brands of food products. Food Quality and Preference, 32, 289-298.

58. Saeed, S. (1994). Consumer evaluation of products in a global market. Journal of International Business Studies, 25(3), 579-604.

59. Salem, M. (2018). Effects of perfume packaging on Basque female consumers purchase decision in Spain. Management Decision, 56(8), 1748-1768.

60. Sarstedt, M., Ringle, M., Smith, D., Reams, R. \& Hair, F. (2014). Partial least squares structural equation modeling (PLS-SEM): A useful tool for family business researchers. Journal of Family Business Strategy, 5(1), 105-115.

61. Sharma, P. (2011). Country of origin effects in developed and emerging markets: Exploring the contrasting roles of materialism and value consciousness. Journal of International Business Studies, 42, 285-306. https://doi.org/10.1057/jibs.2010.16.

62. Shafiq, R., Raza, I., \& Zia-ur-Rehman, M. (2011). Analysis of the factors affecting customers purchase intention: The mediating role of perceived value. African Journal of Business Management, 5(26), 10577-10585.

63. Silayoi, P., \& Speece, M. (2004). Packaging and purchase decision: An exploratory study on the impact of involvement level and time pressure. British Food Journal, 106(8), 607-628.

64. Tih, Siohong \& Kean Heng Lee. (2017). Perceptions and predictors of consumers' purchase intentions for store brands: Evidence from Malaysia. Asian Journal of Business and Accounting, 6(2). Retrieved from HYPERLINK "https:/ajba.um.edu.my/ article/view/2679" \t "_new" https:/ajba.um.edu.my/article/view/2679

65. Tung, S.Y., Lim, C.S., \& Wong, S.C. (2019). Patient's intention to use mobile health app. Journal of Management Research, 11(3), 18-35.

66. Wang, C., \& Lamb, C. (1983). The impact of selected environmental forces upon consumers' willingness to buy foreign products. Journal of the Academy of Marketing Science, 11(2), 71-84.

67. Wang, C.L., Li, D., Barnes, B.R., \& Ahn, J. (2012). Country image, product image and consumer purchase intention: Evidence from an emerging economy. International Business Review, 21(6), 1041-1051. HYPERLINK "https://doi.org/10.1016/ j.ibusrev.2011.11.010" https://doi.org/10.1016/j.ibusrev.2011.11.010 .

68. Yang, R., Ramsaran, R., \& Wibowo, S. (2016). A conceptual model for country of origin effect. Asia Pacific Institute of Advanced Research, 2(1), 96-116.

69. Yasin, N., Noor, M., \& Mohamad, O. (2007). Does image of country-of-origin matter to brand equity? Journal of Product \& Brand Management, 16(1), 38-48.

70. Zeithaml, V.A. (1988). Consumer perceptions of price, quality, and value: A means-end model and synthesis of evidence. Journal of Marketing, 52(3), 2-22. https://doi.org/10.1177\%2F002224298805200302.

71. Zekiri, J., \& Hasani, V. (2015). The role and impact of the packaging effect on the consumer buying behaviour. Eco Forum Journal, 4(1), 232-240. 
Lim Chui Seong, DBA - Faculty of Business, Economic and Accounting, Business Department. Her research interests are in the area of marketing, consumer's behavior, e-commerce and social entrepreneurialship and management.

Doctor of Business Administration in Marketing from National University of Malaysia (UKM).

Hong Kay Tze, PhD - Faculty of Business and Law, School of Management and Marketing. She completed her PhD (Business Economics) in 2018, from University of Putra Malaysia. She has authored and co-authored many articles in refereed and professional journals including International Journal of Economics and Management, Review of Business Management, International Journal of Human Resource Studies and International Journal of Business and Society. Her research interests are in the area of marketing, consumer's behavior, retailing and corporate social responsibility.

Doctor of Philosophy in Business Economics from University Putra Malaysia.

Wong Siew Chin, PhD - Faculty of Business, Economics and Accounting, HELP University, Malaysia. Her research interests are human resource development, career development and organizational behavior. Currently, her research focuses on career development among public and private sectors employees. Doctor of Philosophy in Human Resources Management from University Putra Malaysia. 